Article

\title{
Does the Exhaustion of Resources Drive Land Use Changes? Evidence from the Influence of Coal Resources-Exhaustion on Coal Resources-Based Industry Land Use Changes
}

\author{
Bo Wen ${ }^{1}$, Yunhua Pan ${ }^{2}$, Yanyuan Zhang ${ }^{3}$, Jingjie Liu ${ }^{4}$ and Min Xia ${ }^{4, *}$ \\ 1 College of Horticulture, Nanjing Agricultural University, Nanjing 210095, China; njauwb@njau.edu.cn \\ 2 Institute of Soft Science on Transformation and Development of Resource-Exhausted Cities, Pingxiang \\ University, Pingxiang 337000, China; yhpan1963@126.com \\ 3 College of Economics and Management, Nanjing Forestry University, Nanjing 210037, China; \\ yyzhang@njfu.edu.cn \\ 4 College of Public Administration, Nanjing Agricultural University, Nanjing 210095, China; \\ 2014209019@njau.edu.cn \\ * Correspondence: xm@njau.edu.cn; Tel.: +86-025-8439-5700
}

Received: 3 July 2018; Accepted: 31 July 2018; Published: 1 August 2018

\begin{abstract}
Analyzing the spatial-temporal changes of resources-based industrial land is essential to the transformation and development of resources-exhausted cities. In this paper, we studied coal resources-based industrial land use changes and their driving factors in a typical coal resources-exhausted city, Anyuan District, Pingxiang city. The changes between coal resources-based industrial land and other land-use types were analyzed. The logistic regression models were applied to identify the main driving factors and quantify their contributions to coal resources-based industrial land-use changes during the two periods of 2003-2008 and 2008-2013. The results show that coal resources-based industrial land declined by 34.37\% during the period 2008-2013 as coal resources were being exhausted. Altitude, distance to roads, distance to town, population density change, fixed-asset investment per area change, and GDP per capita change drove coal resources-based industrial land-use changes. However, the patterns of the driving effects differed, and even the same factors had different influences on coal resources-based industrial land-use changes during the two periods. The changes in the driving factors can be seen as responses to socioeconomic transformation and development in the city, which is experiencing the exhaustion of coal resources. As a result of the comprehensive effects of these driving factors, coal resources-based industrial land use has changed in complex ways.
\end{abstract}

Keywords: coal resources-based industrial land-use changes; driving factors; logistic regression model; resources-exhausted city; Anyuan District

\section{Introduction}

Nowadays resources-exhausted cities whose economy used to rely on development of the natural resources such as mineral resources, forest resources and so on are facing the phenomenon of resource exhaustion. The cumulative extraction of resources in these cities has reached more than $70 \%$ of recoverable reserves and resource exploitation has come to the end stage [1]. In recent years, resources extraction and initial processing enterprises in these cities had gradually closed, causing a dramatic change of industrial land. On the one hand, enormous abandoned industrial land brings environmental problems [2,3]. On the other hand, there is an urgent need for construction land in 
economic transformation and sustainable development of these cities [4]. However, few studies have explored coal resources-based industrial land-use changes and their driving forces.

In recent decades, dramatic land-use changes have occurred around the world, especially in rapidly developing regions $[5,6]$. As an important component of global environmental change, land use and cover change (LUCC) has become a hot topic in sustainable development studies $[7,8]$. Increasing numbers of studies have investigated land-use changes and their driving forces [9-11], including comprehensive land-use changes [12,13], construction land-use changes [14-16], farmland changes [17-19], and ecological land changes [20,21]. Generally speaking, researchers believe that natural environment changes, industrialization and urbanization are the main driving forces in the conversion of farmland to nonagricultural use [22-24]. Socioeconomic developments and land-use policies drive urban and industrial land expansion for future urban land-use spaces $[25,26]$. On the other hand, the wetland and forest has increased and environment has improved with the ecological restoration projects are implemented [27]. Most of these studies are focused on large-scale or mesoscale land use changes and their driving forces [28-30]. At different spatial scales, the interactions between land use change and its associated factors are also different [31-33]. An in-depth study of small-scale land-use changes can further reveal the micro-processes and internal mechanisms of regional spatial-temporal changes in land use [34]. Moreover, as a special and important land use type in resources-exhausted cities, resources-based industrial land use changes are related to the phases of coal resources-based cities, which include the two different phases of prosperity and exhaustion. Analyzing the spatial-temporal changes of resources-based industrial land is essential to provide important information for its reasonable use and reclamation, and is beneficial to the transformation and development of these cities. Therefore, it is necessary to expand the research to coal resources-based industrial land-use changes and their driving forces at a small scale.

Pingxiang is a typical coal resources-exhausted city located in Jiangxi province in China. Anyuan District in Pingxiang was selected in this study to explore coal resources-based industrial land-use changes and their driving forces. By the using of high-resolution images from 2003, 2008 and 2013, changes in coal resources-based industrial land areas and their directions of flow were considered to determine spatiotemporal characteristics. The possible driving forces and their impact on coal resources-based industrial land-use changes were spatially identified and quantified using logistic regression models.

\section{Overview of the Study Region}

Anyuan District is situated in the hilly and mountainous area of central China, lying between $113^{\circ} 45^{\prime}-113^{\circ} 59^{\prime} \mathrm{E}$ and $27^{\circ} 33^{\prime}-27^{\circ} 44^{\prime} \mathrm{N}$ (Figure 1). It is the political, economic, and cultural center of Pingxiang in Jiangxi province. The landform is plain in the northwest part of the study area and mountainous in the southeast. The east-west width is about $22.75 \mathrm{~km}$, and the north-south length is about $20.33 \mathrm{~km}$, covering an area of approximately $212.58 \mathrm{~km}^{2}$. The area is located in a humid subtropical monsoon climate zone and is characterized by four distinct seasons with an average annual precipitation of $1630 \mathrm{~mm}$ and a mean annual temperature of $17.2^{\circ} \mathrm{C}$. The annual rainfall is higher than the annual evaporation. Anyuan District is among the earliest recorded coal mining areas in China and can be traced back to the Tang Dynasty. In the past, it was called the "Coal Capital" south of the Yangtze River because of its abundant coal resources. Coal resources-based industrial land is the main component of industrial land. As they are located in hilly and mountainous areas, coal mines are widely distributed at relatively high altitudes. The exploitation of coal resources has greatly contributed to the modernization of the region, as well as the whole country. As a result of high-intensity coal mining over a long period, coal resources in Anyuan District since 2000 have become nearly exhausted, resulting in a reduction of coal mining and coal processing activities. The coal economy is collapsing. In March 2008, the State Development and Reform Commission identified Pingxiang as a resources-exhausted city. As the most important coal production area of Pingxiang, Anyuan District is experiencing dilemmas in both its socioeconomic and ecological development. 


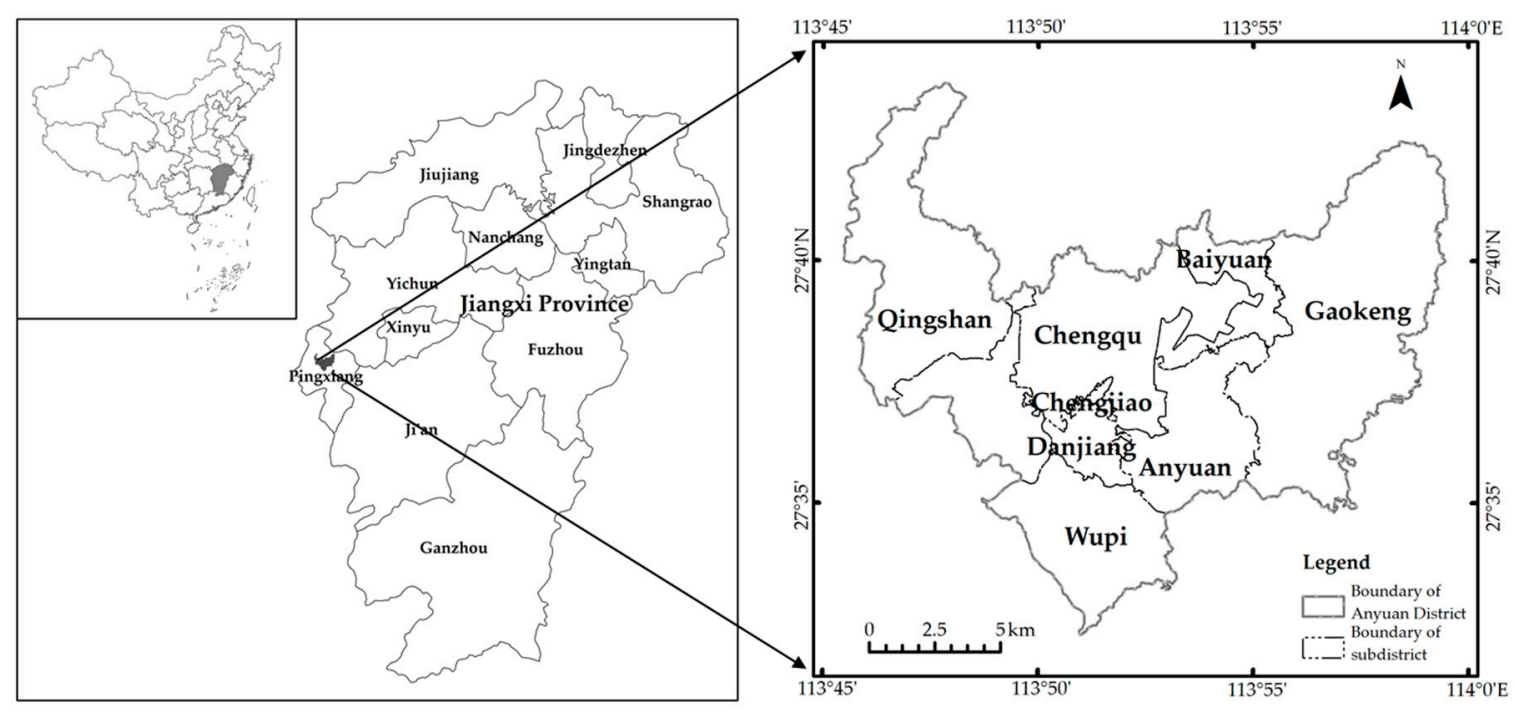

Figure 1. Location of Anyuan District.

\section{Data Sources and Methods}

\subsection{Data Sources}

SPOT images from 2003 and aerial photographs from 2008 and 2013 obtained from the Pingxiang Municipal Bureau of Land and Resources were chosen as the base images. The resolution of the SPOT images is $2.5 \mathrm{~m}$, and the resolution of the aerial photography images is $1 \mathrm{~m}$. The images from 2003, 2008 and 2013 were geo-referenced and imported into a Gauss-Kruger coordinate system. An accuracy of less than 0.5 pixel root mean square error was achieved using image rectification in ERDAS Imagine 9.2 software. The land-use categories were divided into six kinds: Coal resources-based industrial land, general construction land, farmland, forestland, and other use types by the objected-based classification method. In the study, coal resources-based industrial land refers to land used for coal mining, coal product processing and coal storage. The land use data of the corresponding periods and high-resolution images from Google Earth were used as reference data. At the same time, the coal resources-based industrial land and the changes were revised according to the investigation of mine management bureau and the village cadres of the area. The accuracy of the comprehensive evaluation of results was more than $86 \%$ [35]. All images were converted into a grid map with $2.5 \mathrm{~m}$ resolution to reduce errors in counting the data. To obtain gains and losses in coal resources-based industrial land during the periods of 2003-2008 and 2008-2013, the land-use maps for 2003, 2008 and 2013 were overlaid using ArcGIS 10.3 software (Figure 2). Slope and altitude data were extracted from ASTER GDEM data (30 m resolution) obtained from the Geospatial Data Cloud, Chinese Academy of Sciences (http:/ / www.gscloud.cn). The data for distances to roads and towns were calculated using the ArcGIS. The socioeconomic data including urbanization rates, financial revenues, population, and fixed-asset investment were collected from Anyuan District's yearbooks for 2004-2014. These data were assigned to the sub-districts of Anyuan District's vector layer, and converted to raster layers with a resolution of $30 \mathrm{~m}$ [36]. It is important to note that we take the changes of the data from 2003-2008, and from 2008-2013 into consideration, therefore, the study is actually based on cross-sectional data for two periods. 

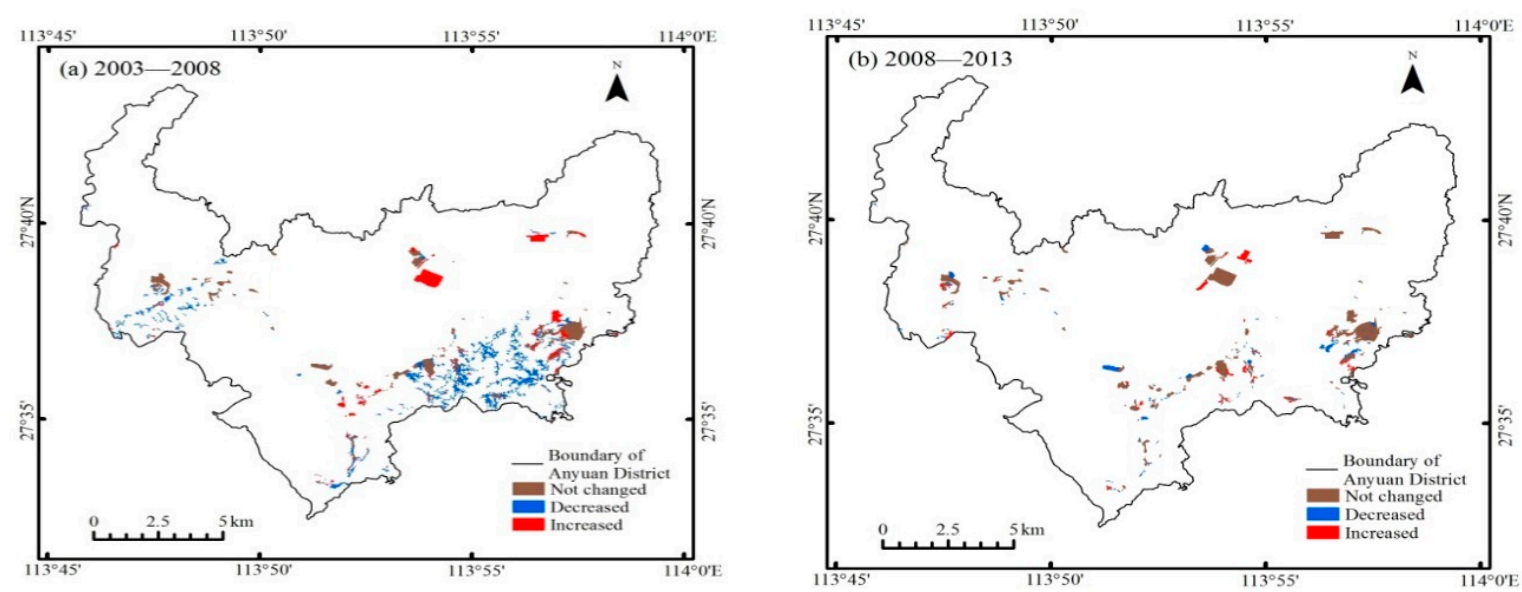

Figure 2. Changes in coal resources-based industrial land in Anyuan District.

\subsection{Driving Factors Analysis of Industrial Land-Use Change}

At any point on the earth's surface, land-use change can be divided into two types: Changed or not changed. Regression model was popular in the quantitative analysis of land-use change driving factors. However, the traditional linear regression model is not applicable for solving this problem with a dichotomous dependent variable [37-39]. In this situation, the logistic regression model has the advantage of addressing this problem properly as it is a nonlinear model for binary or multivariate analysis [40]. Therefore, logistic regression models are often used to analyze the driving forces in land-use changes [36,41,42]. In this study, coal resources-based industrial land-use change was considered the dependent variable $(Y)$ with a binary value (i.e., changed or not changed), linked to a series of possible driving factors $(X)$, with the following logistic regression equation [43]:

$$
P=\operatorname{Prob}(Y=1 \mid X)=\frac{e^{X^{\prime} \beta}}{1+e^{X^{\prime} \beta}}=\Lambda\left(X^{\prime} \beta\right)
$$

where $\Lambda(\cdot)$ represents the standard logistic cumulative distribution function. $P$ is the occurrence probability of coal resources-based industrial land-use change, and $\beta$ is a vector of parameters to be estimated. While the coefficients of logistic model only provide the direction and significance of explanatory variables, marginal effects which shows how much the event probability changes when a given explanatory variable is changed by one unit usually need to be computed. When one of the driving factors $X_{k}$ is a continuous variable, its partial effect on coal resources-based industrial land-use change is obtained from the partial derivative:

$$
\frac{\partial \operatorname{Prob}(Y=1 \mid X)}{\partial X_{k}}=\frac{d \Lambda\left(X^{\prime} \beta\right)}{d\left(X^{\prime} \beta\right)} \beta_{k}=\frac{e^{X^{\prime} \beta}}{\left(1+e^{X^{\prime} \beta}\right)^{2}} \beta_{k}=\Lambda\left(X^{\prime} \beta\right)\left[1-\Lambda\left(X^{\prime} \beta\right)\right] \beta_{k}
$$

The explanatory variable will only pass the significance test if the associated p-value of the $z$-statistic is less than the given significance level (0.05 in our study). In addition, socioeconomic data including urbanization rates, financial revenues, population, and fixed-asset investment are based on Anyuan District's yearbooks for 2004-2014, which is measured at an aggregation level. However, the dependent variable is measured as a detailed spatial unit. The different measurement level of dependent variable and explanatory variables may lead to a bias in standard errors. Therefore, we use clustered adjusted standard errors to alleviate this problem [44]. 


\subsection{Selection of Driving Factors}

Previous studies have shown that land-use change is a complex process that is affected by the comprehensive effects of natural environment changes and human activity [45-47]. As a special land-use type, coal resources-based industrial land-use change is also affected by changes in the natural environment and human activity. After investigating the status of coal resources-based industrial land-use changes, physical geography conditions, location conditions, and socioeconomic conditions in Anyuan District-and combining them with principles of driving-factor selection such as representativeness, comprehensiveness, and data availability -9 possible driving factors were selected. However, financial revenue per area, which had a strong collinear relationship with other driving factors, was excluded. Thus, 8 independent variables were finally selected as possible driving factors (Table 1). In these driving factors, slope and altitude represent natural driving factors; distances to roads and towns represent location driving factors; and population density change, fixed-asset investment per area change, urbanization rate change, and GDP per capita change represent socioeconomic driving factors. Changes in socioeconomic factors were calculated in terms of the difference between the two periods of 2003-2008 and 2008-2013. The socioeconomic data were assigned to the towns of Anyuan District as attribute data in vector layers using ArcGIS 10.3. Finally, maps of the driving factors were converted to $30 \mathrm{~m}$ resolution grid maps to facilitate sampling.

Table 1. Description and value assignment of variables.

\begin{tabular}{|c|c|c|c|}
\hline & Variable & Type & Range of Variables \\
\hline \multirow{2}{*}{$\begin{array}{l}\text { Dependent } \\
\text { variables }\end{array}$} & Coal resources-based industrial land gain & Binary-categorical & 0 or 1 \\
\hline & Coal resources-based industrial land loss & Binary-categorical & 0 or 1 \\
\hline \multirow{11}{*}{$\begin{array}{l}\text { Independent } \\
\text { variables }\end{array}$} & Physical geography factors & & \\
\hline & Slope ${ }^{\circ}$ & Continuous & 0 to 31.83 \\
\hline & Altitude/m & Continuous & 81 to 478 \\
\hline & Location factors & & \\
\hline & Distance to roads $/ \mathrm{m}$ & Continuous & 0 to 4309.19 \\
\hline & Distance to town/m & Continuous & 0 to 7332.11 \\
\hline & Socioeconomic factors & & \\
\hline & Population density change/persons $/ \mathrm{hm}^{2}$ & Continuous & -1.31 to 3.05 \\
\hline & Fixed-asset investment per area change $/ 10^{4}$ yuan $/ \mathrm{hm}^{2}$ & Continuous & 11.44 to 194.13 \\
\hline & Urbanization rate change $/ \%$ & Continuous & -7.22 to 30.75 \\
\hline & GDP per capita change $/ 10^{4}$ yuan/ per capita & Continuous & 0.61 to 7.14 \\
\hline
\end{tabular}

\subsection{Spatial Sampling}

To avoid spatial autocorrelation, stratified random sampling was used by creating a random point tool in ArcGIS, and $n$ observations were selected randomly throughout the study area. For every observation, the data for dependent and independent variables were extracted from coal resources-based industrial land-use changes and driving factor layers, and 200 sampling points were finally retained. For each sampling point, 1 was assigned if the changes between coal resources-based industrial land and other land-use types occurred during the two periods of 2003-2008 and 2008-2013; otherwise, 0 was assigned. Using the same observations, the data were extracted from the driving factor maps as the independent variable. To avoid influence on the constant term, the number of observations with values of 0 and 1 was equal in every model $[48,49]$. Since the independent variables were selected from natural conditions, socioeconomic conditions, location, and so on, the sampled data have different dimensions and dimensional units. To eliminate the influence of the dimension, the sampled data were standardized using the standard scores standardization method using the following expression [36]:

$$
X_{i, j}^{\prime}=\frac{X_{i, j}}{\bar{X}_{i}}(i=\mathbf{1}, \mathbf{2}, \cdots, n ; j=\mathbf{1}, \mathbf{2}, \cdots, m)
$$


where $X_{i, j}^{\prime}$ stands for the standardization result; $X_{i, j}$ is the raw value of the $i$ th possible driving factor in the $j$ th sampling point; $\bar{X}_{\mathrm{i}}$ is the mean of the $i$ th possible driving factor for all sampling points. Once all the data were ready, Stata 12 was used to construct the logistic regression models and analyze the driving forces of coal resources-based industrial land-use change.

\section{Research Results}

\subsection{Coal Resources-Based Industrial Land-Use Change}

Figure 3 shows the area for each type of land use in Anyuan District from 2003 to 2013. To analyze coal resources-based industrial land-use changes, the land-use transition between coal resources-based industrial land and non-coal resources-based industrial land during 2003-2013 was calculated using a land-use change matrix. Table 2 shows the results of the land-use change matrix for 2003-2013 in Anyuan District.

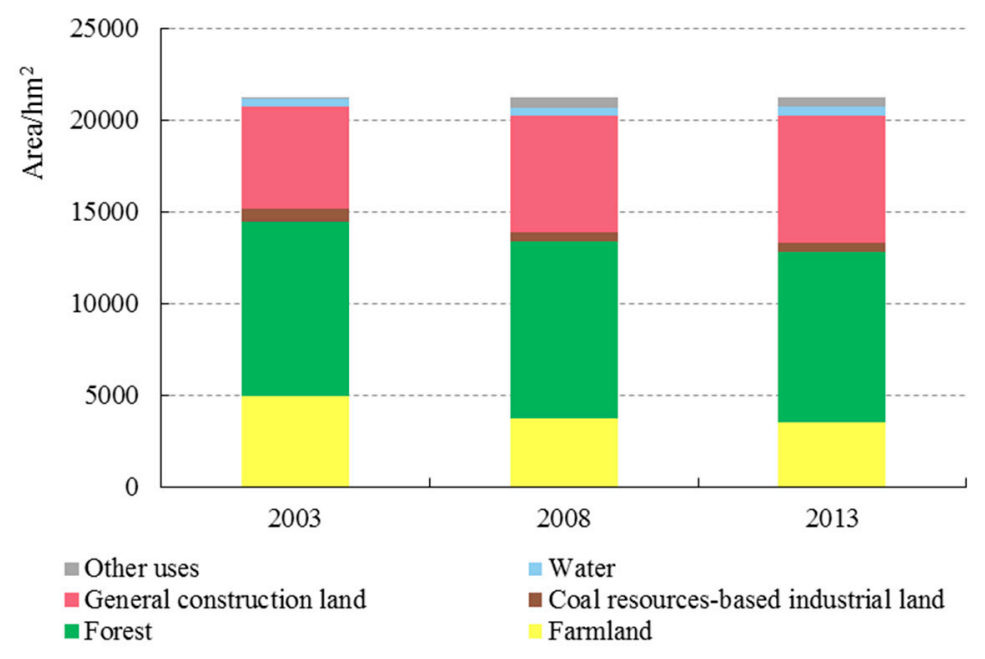

Figure 3. Area for each type of land use in Anyuan District during the period 2003-2013.

Table 2. Land-use change matrix from 2003 to 2013 in Anyuan District $\left(\mathrm{hm}^{2}\right)$.

\begin{tabular}{cccccccc}
\hline & Farmland & Forest & $\begin{array}{c}\text { Coal } \\
\text { Resources-Based } \\
\text { Industrial Land }\end{array}$ & $\begin{array}{c}\text { General } \\
\text { Construction } \\
\text { Land }\end{array}$ & Water & Others & 2003 Total \\
\hline Farmland & 3009.57 & 789.83 & 36.61 & 928.09 & 129.95 & 81.86 & 4975.91 \\
\hline Forest & 277.08 & 7998.37 & 66.82 & 847.61 & 28.17 & 281.15 & 9499.20 \\
\hline $\begin{array}{c}\text { Coal resources-based } \\
\text { industrial land }\end{array}$ & 10.68 & 152.36 & 273.24 & 179.60 & 1.08 & 127.03 & 743.99 \\
\hline $\begin{array}{c}\text { General construction } \\
\text { land }\end{array}$ & 158.15 & 294.90 & 109.70 & 4938.95 & 27.53 & 26.78 & 5556.01 \\
\hline Water & 57.39 & 31.16 & 0.96 & 80.04 & 258.52 & 8.93 & 437.00 \\
\hline Others & 4.74 & 35.54 & 0.97 & 6.32 & 0.52 & 9.55 & 57.64 \\
\hline 2013 total & 3517.61 & 9302.16 & 488.30 & 6980.61 & 445.77 & 535.30 & $21,269.75$ \\
\hline
\end{tabular}

During the period 2003-2013, the area of farmland, forest, and coal resources-based industrial land decreased. The area of general construction land and other land types increased, and the area of water remained mostly steady over the same period. Anyuan District is the urban area of Pingxiang City whose residential space is the main construction land. Although coal resources-based industrial land accounts for a small proportion of construction land, it accounts for a large proportion of industrial land. The total area of coal resources-based industrial land was $743.99 \mathrm{hm}^{2}$ in $2003,498.55 \mathrm{hm}^{2}$ in 2008 , and $488.30 \mathrm{hm}^{2}$ in 2013, which represents a dramatic decrease during 2003 to 2008. 
Of the total reduced coal resources-based industrial land, 38.15\% was converted to general construction land (area: $179.60 \mathrm{hm}^{2}$ ), $32.37 \%$ was converted to forest (area: $152.36 \mathrm{hm}^{2}$ ), and $26.98 \%$ was converted to other land-use types (area: $127.03 \mathrm{hm}^{2}$ ). On the other hand, some general construction land, forest, and farmland were converted to coal resources-based industrial land. General construction land increased $25.64 \%$ from $5556.01 \mathrm{hm}^{2}$ to $6980.61 \mathrm{hm}^{2}$ whereas $109.70 \mathrm{hm}^{2}$ of general construction land was converted to coal resources-based industrial land. Farmland and forest were reduced by $29.31 \%$ (from $4975.91 \mathrm{hm}^{2}$ to $3517.61 \mathrm{hm}^{2}$ ) and $2.07 \%$ (from $9499.20 \mathrm{hm}^{2}$ to $9302.16 \mathrm{hm}^{2}$ ), respectively. Of the total reduced area in these two types, $66.82 \mathrm{hm}^{2}$ of forest and $36.61 \mathrm{hm}^{2}$ of farmland were converted to coal resources-based industrial land.

\subsection{Factors Driving Changes in Industrial Land-Use}

\subsubsection{Driving Factors of Industrial Land-Use Change, 2003-2008}

Table 3 shows the coefficients, clustered adjusted standard errors and marginal effects of the two logistic regression models for the driving factors of coal resources-based industrial land-use losses and gains from 2003 to 2008 .

Table 3. Results of the logistic regression models for coal resources-based industrial land-use changes, 2003-2008.

\begin{tabular}{|c|c|c|c|c|c|c|}
\hline \multirow{2}{*}{ Driving Factors } & \multicolumn{3}{|c|}{$\begin{array}{l}\text { Model } 1 \text { Coal Resources-Based } \\
\text { Industrial Land Loss }\end{array}$} & \multicolumn{3}{|c|}{$\begin{array}{l}\text { Model } 2 \text { Coal Resources-Based } \\
\text { Industrial Land Gain }\end{array}$} \\
\hline & Coef. & $\begin{array}{l}\text { Clustered } \\
\text { Adjusted SE }\end{array}$ & $\mathrm{dy} / \mathrm{dx}$ & Coef. & $\begin{array}{c}\text { Clustered } \\
\text { Adjusted SE }\end{array}$ & $\mathrm{dy} / \mathrm{dx}$ \\
\hline Slope & -0.251 & 0.402 & -0.030 & 0.005 & 0.149 & 0.001 \\
\hline Altitude & $0.930^{* * *}$ & 0.236 & $0.111^{* * *}$ & 0.096 & 0.230 & 0.022 \\
\hline Distance to roads & $1.938^{* * *}$ & 0.158 & $0.231 * * *$ & -0.196 & 0.466 & -0.045 \\
\hline Distance to town & $0.796^{* * *}$ & 0.191 & $0.095^{* * *}$ & $-0.526^{* * *}$ & 0.191 & $-0.122 * * *$ \\
\hline Population density change & $1.283^{* * *}$ & 0.355 & $0.153^{* * *}$ & 0.158 & 0.599 & 0.037 \\
\hline Fixed-asset investment per area change & $-1.912 * *$ & 0.976 & $-0.228 *$ & 0.144 & 1.142 & 0.033 \\
\hline Urbanization rate change & -0.636 & 0.550 & -0.076 & -0.254 & 0.695 & -0.059 \\
\hline GDP per capita change & -0.594 & 1.051 & -0.071 & 0.360 & 1.308 & 0.083 \\
\hline Constant & $0.543^{* * *}$ & 0.105 & - & -0.024 & 0.239 & - \\
\hline Number of observations & & 200 & & & & 200 \\
\hline
\end{tabular}

Note: ${ }^{*}, * *$, and ${ }^{* * *}$ denote variables significant at the $10 \%, 5 \%$ and $1 \%$ levels, respectively.

In model 1, altitude, distance to roads, distance to town, population density change, and fixed-asset investment per area change have significant effect on the loss of coal resources-based industrial land. Altitude has positive impact on coal resources-based industrial land loss: One unit increase in altitude will produce 0.111 units increase in the probability of coal resources-based industrial land loss. Given the difficulty of coal mining at higher altitudes, industrial land with the exhaustion of coal resources is more likely to be transferred. Distance to roads and distance to town as location factors positively affect coal resources-based industrial land loss: With one unit increase in these two factors, the probabilities of coal resources-based industrial land loss increase by 0.231 units and 0.095 units, respectively. Generally speaking, most of the coal mines are located in the hilly and mountainous regions far away from the town. The probability of coal resources-based industrial land loss increases indicates that more coal resources-based industrial land changes to other land use types. This is mainly because coal declined in quality during the period of coal-resources exhaustion and could not be sold at good prices, and long-distance transportation increases production costs. Population density change is another important driving factor that positively affects coal resources-based industrial land loss. Loss is more likely to occur in regions with higher population density. With a one unit increase in population density, the probability of coal resources-based industrial land loss increases by 0.153 units. Population agglomeration drives socioeconomic development. As a consequence, when the coal industry declines, labor forces and capitals that originally worked or invested in small 
and micro coal enterprises transfer to other industries for higher profits, which caused changes in coal resources-based industrial land use. It was found that many coal enterprises, especially small and micro private coal enterprises, shut down between 2003 and 2008. Further, the variable of fixed-asset investment per area change has negative impact on coal resources-based industrial land loss. With one unit increase in fixed-asset investment per area, the probabilities of coal resources-based industrial land loss decreased by 0.228 units. The reason for this could be that to ensure industrial output value, the government increased investment in the mining industry, since coal is the leading industry in the area.

In model 2, only the variable of distance to town passes the significance test. Distance to town has a negative impact on coal resources-based industrial land gain. One unit increase in distance to town will produce a 0.122 units decrease in the probability of coal resources-based industrial land gain. The probability of coal resources-based industrial land gain declines indicates that it is more difficult to make the other land use types change to coal resources-based industrial land. With the coal-resources exhaustion, the difficulties of coal exploitation and the costs of production increased and as a result, the expanding of land for coal mining became more and more difficult.

\subsubsection{Factors Influencing Industrial Land-Use Change, 2008-2013}

Table 4 shows the results of the logistic regression models for the driving factors of coal resources-based industrial land losses and gains during the period 2008-2013. In model 3, altitude, distance to roads, distance to town, population density change, fixed-asset investment per area change and GDP per capita change significantly affect the loss of coal resources-based industrial land. Altitude has positive impact on coal resources-based industrial land loss: With a one unit increase in altitude, the probability of coal resources-based industrial land loss increases by 0.125 units. This suggests that coal resources-based industrial land at higher altitudes is more likely to be transferred. It was found that with the aggravation of coal-resource exhaustion during this period, coal shortages caused the exit of state-owned coal enterprises. Distance to roads has a negative impact on coal resources-based industrial land loss: With a one unit increase in distance to roads, the probability of coal resources-based industrial land loss decreases by 0.186 units. Meanwhile, distance to town positively affects coal resources-based industrial land loss: With one unit increase in distance to town, the probability of coal resources-based industrial land loss increases by 0.128 units. This is mainly because coal mining, processes, and storage cannot generate satisfactory profits in advantageous locations, and the coal resources-based industrial lands near roads are likely to change to other land types. At the same time, other coal mining enterprises that are far from towns are in continuous recession as coal resources become exhausted. As for socioeconomic factors, population density change, fixed-asset investment per area change, and GDP per capita change positively affect coal resources-based industrial land loss. With one unit increase in these three factors, the probabilities of coal resources-based industrial land losses increase 0.235 units, 0.242 units and 0.118 units, respectively. Along with socioeconomic transformation and development, the coal industry-previously the area's leading industry-is replaced by other industries, and capital, labor, and other production factors flow into the new leading industries with higher outputs. Therefore, these factors accelerate coal resources-based industrial land loss.

Similarly to Model 2, only the variables of distance to town passed the significance test at the $1 \%$ significance level in model 4 . As with 2003-2008, distance to town negatively affected coal resources-based industrial land increase during this period. A one unit increase in distance to town will produce a 0.145 units decrease in the probability of coal resources-based industrial land gain. 
Table 4. Results of the logistic regression models for coal resources-based industrial land-use changes, 2008-2013.

\begin{tabular}{ccccccc}
\hline \multirow{2}{*}{ Driving Factors } & \multicolumn{2}{c}{$\begin{array}{c}\text { Model 3 Coal Resources-Based } \\
\text { Industrial Land Loss }\end{array}$} & \multicolumn{2}{c}{$\begin{array}{c}\text { Model 4 Coal Resources-Based } \\
\text { Industrial Land Gain }\end{array}$} \\
\cline { 2 - 7 } & Coef. & $\begin{array}{c}\text { Clustered } \\
\text { Adjusted SE }\end{array}$ & dy/dx & Coef. & $\begin{array}{c}\text { Clustered } \\
\text { Adjusted SE }\end{array}$ & dy/dx \\
\hline Slope & 0.219 & 0.137 & $0.049^{*}$ & 0.118 & 0.316 & 0.025 \\
Altitude & $0.560^{* * *}$ & 0.215 & $0.125^{* * *}$ & 0.875 & 0.593 & $0.185^{*}$ \\
Distance to roads & $-0.835^{* *}$ & 0.414 & $-0.186^{* *}$ & -0.032 & 0.314 & -0.007 \\
Distance to town & $0.575^{* * *}$ & 0.183 & $0.128^{* * *}$ & $-0.686^{* * *}$ & 0.239 & $-0.145^{* * *}$ \\
Population density change & $1.054^{* * *}$ & 0.165 & $0.235^{* * *}$ & -0.161 & 0.244 & -0.034 \\
Fixed-asset investment per area change & $1.086^{* * *}$ & 0.206 & $0.242^{* * *}$ & -0.003 & 0.334 & -0.001 \\
Urbanization rate change & -0.110 & 0.124 & -0.024 & 0.263 & 0.259 & 0.056 \\
GDP per capita change & $0.530^{* * *}$ & 0.098 & $0.118^{* * *}$ & 0.083 & 0.187 & 0.017 \\
Constant & 0.219 & 0.056 & - & 0.006 & 0.087 & - \\
Number of observations & \multicolumn{7}{c}{200} & & & 200 & \\
\hline
\end{tabular}

\section{Discussion}

\subsection{Exhaustion of Coal Resources Improves the Land Environment Indirectly}

The prosperity of mining activities will lead to a rapid reduction in the scale of ecological land such as forests and result in some ecological environment problems [50,51]. After high-intensity coal mining over a long period, the coal resources had been exhausted from 2000 in the Anyuan District. At the first stage of 2003 to 2008, small and micro coal enterprises were rapidly shut down because of the lack of capital and labor, causing a dramatic decrease of coal resources-based industrial land. Although the state-owned coal enterprises possessing advanced production equipment and technology remained, the exhaustion of coal resources had influenced their production capacity, which led to a long-term decrease of coal resources-based industrial land. With the implementation of the policy of environmental improvement for abandoned mine, the reduced coal resources-based industrial land was converted to forest with the area of $152.36 \mathrm{hm}^{2}$ from 2003 to 2013, which went through a process from abandonment to recovery (Figure 4). With the depletion of coal resources and demand for urban transformation and development, the structure and function of the ecosystem have been restored under the help of self-repair and artificial restoration. Although the exhaustion of coal resources does not directly promote ecological restoration, the land's environmental conditions improve indirectly.

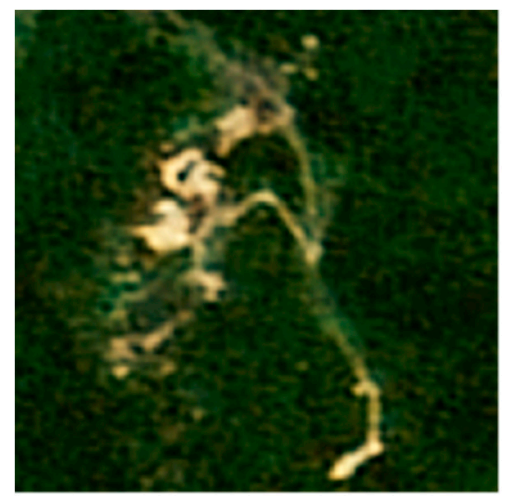

(a) 2003

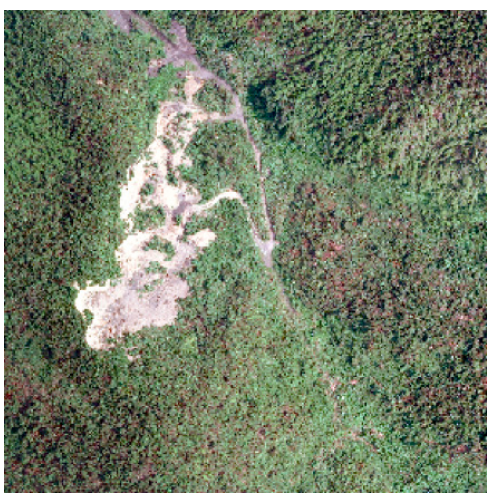

(b) 2008

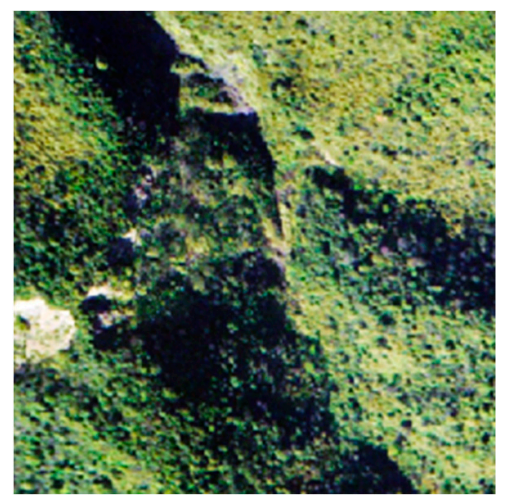

(c) 2013

Figure 4. Vegetation covers change from 2003 to 2013. (a): vegetation cover in 2003; (b): vegetation cover in 2008; (c): vegetation cover in 2013. 


\subsection{Complexity of Coal Resources-Based Industrial Land Changes Driving Factors}

It has been shown that the processes of land-use changes are closely related to environmental changes, population increases, socioeconomic developments, and land-use policies [24,52,53]. Natural factors control long-term and large scale land use change while socioeconomic factors play a leading role in short-term and small scale land use change [12]. For different land use types, the driving factors and the driving mechanism of factors are different. As a special type of land use, coal resources-based industrial land changes have the both directions of increase and decrease in space in the depletion stage of coal resources in this area. The driving forces of social and economic development can also be seen as responses to socioeconomic transformation and development in the city, which is eager to get rid of the development dilemma caused by the exhaustion of coal resources. Apart from the social and economic development driving factors, the altitude is still an important factor influencing coal resources-based industrial land change in the hilly and mountainous areas. This may because the particularity that coal production difficulty will increase with altitude. As a result of the comprehensive effects of these driving factors, the coal resources-based industrial land use changes in complex ways.

\subsection{Bidirectional Process of Coal Resources-Based Industrial Land Changes}

Land use change is a complex process in spatial and temporal dimensions, which could be drastic in a short time under the influence of human activities. In a period of time, the land use change of any point in space is bidirectional [23]. Coal resources-based industrial land refers to land used for coal mining, coal product processing and coal storage, and the role of the driving factors of coal resources-based industrial land gain and loss may be different. Study on the spatiotemporal bidirectional process combining with investigation can help to explore the detailed driving mechanisms of land use change.

\subsection{Influence of Policies on the Coal Resources-Based Industrial Land Changes}

Taking various factors of physical geography, location and socioeconomic into consideration, the driving mechanism of coal resources-based industrial land changes is explained to some extent in this research. In addition to these driving factors, the policies of environment protection, ecological restoration, treatment of abandoned mines and transformation and development of resource exhausted cities can drive the coal resources-based industrial land changes in a short time. Pilot projects addressing waste land in industrial and mining have begun to be carried out in this area and obtained achievements in the improvement of the ecological environment. However, the policy impacts have not been taken into consideration, because the impacts of policies on coal resources-based industrial land changes are still hard to quantify by the logistic regression. The influence of policies on the coal resources-based industrial land changes should be examined in future studies if the data and methods are available.

\section{Conclusions}

Taking Anyuan District as a typical coal resource-exhausted city, this study analyzed coal resources-based industrial land-use changes and quantified the driving factors of physical geography, location, and socioeconomics using logistic regression models. Some conclusions can be drawn as follows.

(1) From 2003 to 2013, the area of coal resources-based industrial land was significantly reduced with the exhaustion of coal resources. Coal resources-based industrial land was mainly converted to general construction land and forest. And some general construction land, forest, and farmland were converted to coal resources-based industrial land.

(2) Factors of physical geography, location, and socioeconomics exerted varying degrees of impact on coal resources-based industrial land gains and losses during the periods of 2003-2008 and 2008-2013. From 2003 to 2008, distance to town was the main factor affecting coal resources-based 
industrial land gains, while altitude, distance to roads, distance to town, population density change, and fixed-asset investment per area change were the main factors affecting the loss of coal resources-based industrial land. From 2008 to 2013, altitude and distance to town drove coal resources-based industrial land gains, while altitude, distance to roads, distance to town, population density change, fixed-asset investment per area change, and GDP per capita change drove coal resources-based industrial land decreases.

(3) Generally speaking, altitude, distance to roads, distance to town, population density change, and fixed-asset investment per area change were the main factors affecting the change of coal resources-based industrial land. Although the driving factors of coal resources-based industrial land gains and losses shared some similarities, the patterns of driving effects were different, and even the same factors had different influences on coal resources-based industrial land-use changes during different periods.

(4) In the exhaustion process of coal resources, the transformation from coal resources-based industrial land into other types of land is the main trend. The land administration department and mine management department should make relevant plans in advance to ensure the orderly transformation of coal resources-based industrial land into other land use types. At the same time, the interests of residents around the mining area, grass-roots governments and other stakeholders need to be considered for sustainable development to occur. Although the study is based on evidence for county scale, it provides a reference for the study of land use change in hilly and mountainous coal resources-exhausted cities.

Author Contributions: B.W. and M.X. had the original idea for this research. Y.P. was responsible for the investigation. Y.Z. and J.L. collected the data. B.W. and M.X. analyzed the data and wrote the paper. All authors have read and approved the final manuscript.

Funding: This research received no external funding.

Acknowledgments: This work was supported by the Soft Science Research Major Program in Jiangxi Province (20161ACA10001), and the MOE (Ministry of Education in China) Projects of Humanities and Social Sciences (16YJAZH064).

Conflicts of Interest: The authors declare no conflict of interest.

\section{References}

1. Zhang, H.; Xiong, L.; Li, L.; Zhang, S. Political incentives, transformation efficiency and resource-exhausted cities. J. Clean. Prod. 2018, 196, 1418-1428. [CrossRef]

2. Fan, J.M.; Hu, S.Y.; Chen, D.J.; Zhou, Y.C. Study on the construction and optimization of a resource-based industrial ecosystem. Resour. Conserv. Recycl. 2017, 119, 97-108. [CrossRef]

3. Yang, D.; Gao, X.; Xu, L.; Guo, Q. Constraint-adaptation challenges and resilience transitions of the industry-environmental system in a resource-dependent city. Resour. Conserv. Recycl. 2018, 134, 196-205. [CrossRef]

4. Cao, Y.G.; Bai, Z.K.; Zhou, W.; Zhang, X.R. Analyses of traits and driving forces on urban land expansion in a typical coal-resource-based city in a loess area. Environ. Earth Sci. 2016, 75, 1191. [CrossRef]

5. Qian, J.; Peng, Y.F.; Luo, C.; Wu, C.; Du, Q.Y. Urban land expansion and sustainable land use policy in shenzhen: A case study of China's rapid urbanization. Sustainability 2016, 8, 16. [CrossRef]

6. Tian, L.; Li, Y.F.; Shao, L.; Zhang, Y. Measuring spatio-temporal characteristics of city expansion and its driving forces in Shanghai from 1990 to 2015. Chin. Geogr. Sci. 2017, 27, 875-890. [CrossRef]

7. Liu, J.Y.; Zhang, Z.X.; Xu, X.L.; Kuang, W.H.; Zhou, W.C.; Zhang, S.W.; Li, R.D.; Yan, C.Z.; Yu, D.S.; $\mathrm{Wu}$, S.X.; et al. Spatial patterns and driving forces of land use change in China during the early 21st century. J. Geogr. Sci. 2010, 20, 483-494. [CrossRef]

8. Turner, B.L.; Lambin, E.F.; Reenberg, A. The emergence of land change science for global environmental change and sustainability. Proc. Natl. Acad. Sci. USA 2007, 104, 20666-20671. [CrossRef] [PubMed]

9. Liu, Y.S.; Wang, L.J.; Long, H.L. Spatio-temporal analysis of land-use conversion in the eastern coastal China during 1996-2005. J. Geogr. Sci. 2008, 18, 274-282. [CrossRef] 
10. Verburg, P.H.; de Koning, G.H.J.; Kok, K.; Veldkamp, A.; Bouma, J. A spatial explicit allocation procedure for modelling the pattern of land use change based upon actual land use. Ecol. Model. 1999, 116, 45-61. [CrossRef]

11. Zhan, J.Y.; Shi, N.N.; He, S.J.; Lin, Y.Z. Factors and mechanism driving the land-use conversion in Jiangxi province. J. Geogr. Sci. 2010, 20, 525-539. [CrossRef]

12. Dong, G.; Xu, E.; Zhang, H. Spatiotemporal variation of driving forces for settlement expansion in different types of counties. Sustainability 2016, 8, 39. [CrossRef]

13. Meneses, B.M.; Reis, E.; Pereira, S.; Vale, M.J.; Reis, R. Understanding driving forces and implications associated with the land use and land cover changes in Portugal. Sustainability 2017, 9, 351. [CrossRef]

14. Wang, J.; Lin, Y.; Glendinning, A.; Xu, Y. Land-use changes and land policies evolution in China's urbanization processes. Land Use Policy 2018, 75, 375-387. [CrossRef]

15. Liu, Y.; Luo, T.; Liu, Z.; Kong, X.; Li, J.; Tan, R. A comparative analysis of urban and rural construction land use change and driving forces: Implications for urban-rural coordination development in Wuhan, central China. Habitat Int. 2015, 47, 113-125. [CrossRef]

16. Chen, Z.; Tang, J.; Wan, J.; Chen, Y. Promotion incentives for local officials and the expansion of urban construction land in China: Using the Yangtze River delta as a case study. Land Use Policy 2017, 63, $214-225$. [CrossRef]

17. Wu, Y.; Shan, L.; Guo, Z.; Peng, Y. Cultivated land protection policies in China facing 2030: Dynamic balance system versus basic farmland zoning. Habitat Int. 2017, 69, 126-138. [CrossRef]

18. Nixon, D.V.; Newman, L. The efficacy and politics of farmland preservation through land use regulation: Changes in southwest British Columbia's agricultural land reserve. Land Use Policy 2016, 59, 227-240. [CrossRef]

19. Xie, H.L.; Zou, J.L.; Jiang, H.L.; Zhang, N.; Choi, Y. Spatiotemporal pattern and driving forces of arable land-use intensity in China: Toward sustainable land management using emergy analysis. Sustainability 2014, 6, 3504-3520. [CrossRef]

20. Xie, H.L.; He, Y.F.; Xie, X. Exploring the factors influencing ecological land change for China's Beijing-Tianjin-Hebei region using big data. J. Clean. Prod. 2017, 142, 677-687. [CrossRef]

21. Hong, W.; Yang, C.; Chen, L.; Zhang, F.; Shen, S.; Guo, R. Ecological control line: A decade of exploration and an innovative path of ecological land management for megacities in China. J. Environ. Manag. 2017, 191, 116-125. [CrossRef] [PubMed]

22. Chen, J.L.; Gao, J.L.; Chen, W. Urban land expansion and the transitional mechanisms in Nanjing, China. Habitat Int. 2016, 53, 274-283. [CrossRef]

23. Chen, Z.; Lu, C.H.; Fan, L. Farmland changes and the driving forces in Yucheng, north China plain. J. Geogr. Sci. 2012, 22, 563-573. [CrossRef]

24. Gao, P.; Niu, X.; Wang, B.; Zheng, Y.L. Land use changes and its driving forces in hilly ecological restoration area based on gis and RS of northern China. Sci. Rep. 2015, 5, 11038. [CrossRef] [PubMed]

25. Chen, J.F.; Chang, K.T.; Karacsonyi, D.; Zhang, X.L. Comparing urban land expansion and its driving factors in Shenzhen and Dongguan, China. Habitat Int. 2014, 43, 61-71. [CrossRef]

26. Kuang, W.H.; Liu, J.Y.; Dong, J.W.; Chi, W.F.; Zhang, C. The rapid and massive urban and industrial land expansions in China between 1990 and 2010: A clud-based analysis of their trajectories, patterns and drivers. Landsc. Urban Plan. 2016, 145, 21-33. [CrossRef]

27. Liu, X.; Zhang, J.; Zhu, X.; Pan, Y.; Liu, Y.; Zhang, D.; Lin, Z. Spatiotemporal changes in vegetation coverage and its driving factors in the three-river headwaters region during 2000-2011. J. Geogr. Sci. 2014, 24, $288-302$. [CrossRef]

28. Li, G.D.; Sun, S.A.; Fang, C.L. The varying driving forces of urban expansion in China: Insights from a spatial-temporal analysis. Landsc. Urban Plan. 2018, 174, 63-77. [CrossRef]

29. Shi, G.; Jiang, N.; Yao, L.Q. Land use and cover change during the rapid economic growth period from 1990 to 2010: A case study of Shanghai. Sustainability 2018, 10, 426. [CrossRef]

30. Wang, J.; Chen, Y.Q.; Shao, X.M.; Zhang, Y.Y.; Cao, Y.G. Land-use changes and policy dimension driving forces in China: Present, trend and future. Land Use Policy 2012, 29, 737-749. [CrossRef]

31. Viedma, O.; Moreno, J.M.; Güngöroglu, C.; Cosgun, U.; Kavgacı, A. Recent land-use and land-cover changes and its driving factors in a fire-prone area of southwestern turkey. J. Environ. Manag. 2017, 197, 719-731. [CrossRef] [PubMed] 
32. Peng, J.; Liu, Y.; Li, T.; Wu, J. Regional ecosystem health response to rural land use change: A case study in Lijiang city, China. Ecol. Indic. 2017, 72, 399-410. [CrossRef]

33. Cegielska, K.; Noszczyk, T.; Kukulska, A.; Szylar, M.; Hernik, J.; Dixon-Gough, R.; Jombach, S.; Valánszki, I.; Filepné Kovács, K. Land use and land cover changes in post-socialist countries: Some observations from Hungary and Poland. Land Use Policy 2018, 78, 1-18. [CrossRef]

34. Chen, C.; Gao, J.; Chen, J. Institutional changes, land use dynamics, and the transition of rural settlements in suburban China: A case study of Huishan district in Wuxi city. Habitat Int. 2017, 70, 24-33. [CrossRef]

35. Li, Y.; Liu, G. Characterizing spatiotemporal pattern of land use change and its driving force based on gis and landscape analysis techniques in Tianjin during 2000-2015. Sustainability 2017, 9, 894. [CrossRef]

36. Gong, Z.; Li, H.; Zhao, W.; Gong, H. Driving forces analysis of reservoir wetland evolution in Beijing during 1984-2010. J. Geogr. Sci. 2013, 23, 753-768. [CrossRef]

37. Shu, B.; Zhang, H.; Li, Y.; Qu, Y.; Chen, L. Spatiotemporal variation analysis of driving forces of urban land spatial expansion using logistic regression: A case study of port towns in Taicang city, China. Habitat Int. 2014, 43, 181-190. [CrossRef]

38. Peng, J.; Zhao, M.; Guo, X.; Pan, Y.; Liu, Y. Spatial-temporal dynamics and associated driving forces of urban ecological land: A case study in Shenzhen city, China. Habitat Int. 2017, 60, 81-90. [CrossRef]

39. Yu, B.H.; Song, W.; Lang, Y.Q. Spatial patterns and driving forces of greenhouse land change in Shouguang city, China. Sustainability 2017, 9, 359. [CrossRef]

40. Newman, M.E.; McLaren, K.P.; Wilson, B.S. Long-term socio-economic and spatial pattern drivers of land cover change in a caribbean tropical moist forest, the cockpit country, Jamaica. Agric. Ecosyst. Environ. 2014, 186, 185-200. [CrossRef]

41. Yeh, C.-K.; Liaw, S.-C. Trajectories, drivers, and probabilities of land cover change in a disturbed forested watershed in eastern Taiwan. Nat. Hazards 2016, 82, 1099-1122. [CrossRef]

42. Lin, Y.; Deng, X.; Li, X.; Ma, E. Comparison of multinomial logistic regression and logistic regression: Which is more efficient in allocating land use? Front. Earth Sci. 2014, 8, 512-523. [CrossRef]

43. Green, W.H. Econometric Analysis, 6th ed.; Prentice Hall: Upper Saddle River, NJ, USA, 2008.

44. Moulton, B.R. An illustration of a pitfall in estimating the effects of aggregate variables on micro units. Rev. Econ. Stat. 1990, 72, 334-338. [CrossRef]

45. Foley, J.A.; Defries, R.; Asner, G.P.; Barford, C.; Bonan, G.; Carpenter, S.R.; Chapin, F.S.; Coe, M.T.; Daily, G.C.; Gibbs, H.K.; et al. Global consequences of land use. Science 2005, 309, 570-574. [CrossRef] [PubMed]

46. Pazúr, R.; Bolliger, J. Land changes in Slovakia: Past processes and future directions. Appl. Geogr. 2017, 85, 163-175. [CrossRef]

47. Turner, B.L.; Meyer, W.B.; Skole, D.L. Global land-use land-cover change-Towards an integrated study. Ambio 1994, 23, 91-95.

48. Deng, Y.; Srinivasan, S. Urban land use change and regional access: A case study in Beijing, China. Habitat Int. 2016, 51, 103-113. [CrossRef]

49. Jiang, W.G.; Wang, W.J.; Chen, Y.H.; Liu, J.; Tang, H.; Hou, P.; Yang, Y.P. Quantifying driving forces of urban wetlands change in Beijing city. J. Geogr. Sci. 2012, 22, 301-314. [CrossRef]

50. Lehmann, D.; Brinkmann, K.; Diogo, R.V.C.; Buerkert, A. Temporal and spatial changes of land use in rare metal mining areas of Rwanda. Int. J. Min. Reclam. Environ. 2017, 31, 519-529. [CrossRef]

51. Pei, W.M.; Yao, S.P.; Knight, J.F.; Dong, S.C.; Pelletier, K.; Rampi, L.P.; Wang, Y.; Klassen, J. Mapping and detection of land use change in a coal mining area using object-based image analysis. Environ. Earth Sci. 2017, 76, 16. [CrossRef]

52. Fu, B.J.; Hu, C.X.; Chen, L.D.; Honnay, O.; Gulinck, H. Evaluating change in agricultural landscape pattern between 1980 and 2000 in the loess hilly region of Ansai county, China. Agric. Ecosyst. Environ. 2006, 114, 387-396. [CrossRef]

53. Long, H.L.; Tang, G.P.; Li, X.B.; Heilig, G.K. Socio-economic driving forces of land-use change in Kunshan, the Yangtze River delta economic area of China. J. Environ. Manag. 2007, 83, 351-364. [CrossRef] [PubMed]

(C) 2018 by the authors. Licensee MDPI, Basel, Switzerland. This article is an open access article distributed under the terms and conditions of the Creative Commons Attribution (CC BY) license (http:/ / creativecommons.org/licenses/by/4.0/). 